\title{
Measuring Internet-Specific Reading Motivation and Engagement in an Academic Domain
}

\author{
Christian Brandmo* and Ivar Bråten \\ University of Oslo
}

\begin{abstract}
The purpose of this study was to develop and test a new measure of motivation and engagement when reading for academic purposes on the Internet. Confirmatory factor analysis of the scores of 386 Norwegian pre-service teachers showed that a seven-factor model including the positive reading motivation and engagement constructs of intrinsic reading motivation, perceived competence in reading, valuing of reading, and dedication to reading, as well as the negative reading motivation and engagement constructs of perceived difficulty of reading, devaluing of reading, and avoidance of reading, fit the data well. Moreover, regression analyses showed that these reading motivation and engagement constructs contributed to time spent on the Internet for academic purposes and academic achievement over and above gender, educational level, teaching practice, and total time spent on the Internet. Taken together, these findings provide preliminary evidence for the construct validity of the measure. The discussion highlights how this measure may be used in future research on the roles of reading motivation and engagement in Internet reading contexts.
\end{abstract}

Keywords: Reading on the Internet; reading motivation and engagement; pre-service teachers; confirmatory factor analysis

Responsible editor: Oddny Judith Solheim

Received: February, 2020; Accepted: October, 2020; Published: January, 2021

\section{Introduction}

The purpose of this study was to develop and test a new measure of motivation and engagement when reading for academic purposes on the Internet. In doing this, we built on extant work in reading psychology highlighting and demonstrating the role of motivation and engagement in learning from text. Of note is that the measure we developed and tested did not target motivation for and engagement in general usage of the Internet for academic purposes but, more specifically, online reading to learn academic content within a particular domain. Accordingly, this study was framed by theory and prior research on reading motivation and engagement.

^Correspondence: Christian Brandmo, e-mail: christian.brandmo@isp.uio.no 
During the last decades, many researchers in reading and literacy have emphasized the importance of constructs of reading motivation as well as reading engagement (e.g., Guthrie et al., 2004; Ng \& Graham, 2018; Schiefele et al., 2012; Wigfield et al., 2016). While cognitive constructs traditionally have received the lion's share of attention within reading research, this burgeoning interest in motivation and engagement constructs has been grounded in a realization that "a cognitive capable reader is only half a reader" (Guthrie \& Klauda, 2016, p. 51). In general, motivation may be distinguished from engagement because motivation refers to internal processes that provide energy for and direction to action, whereas engagement refers to the visible or outward expressions of motivation (Eccles \& Wang, 2012; Skinner et al., 2009; Skinner \& Pitzer, 2012). Within reading research, in particular, reading motivation has been defined as 'individuals' personal goals, values, and beliefs with regard to the topics, processes, and outcome of reading" (Guthrie \& Wigfield, 2000, p. 405), whereas reading engagement has been defined as active involvement in reading activities "as typified by effort, time, and persistence" devoted to reading (Guthrie \& Klauda, 2016, p. 42).

Not surprisingly, the motivation constructs that feature prominently within reading research are derived from more general theories of human motivation. Thus, the influential model of reading engagement proposed by Guthrie and Wigfield (2000) and later refined by Guthrie and colleagues (Guthrie \& Klauda, 2016; Guthrie et al., 2012) draws on self-determination theory (Deci \& Ryan, 2000) in highlighting the role of intrinsic reading motivation, on social-cognitive theory (Bandura, 1997) in highlighting the role of perceived self-efficacy for and competence in reading, and on expectancy-value theory (Wigfield \& Eccles, 2000) in highlighting the role of valuing reading. More specifically, intrinsic reading motivation refers to a willingness to read because the reading is rewarding in its own right, perceived self-efficacy and competence refer to judgments of one's capacity to perform well on future and current reading tasks, and valuing reading refers to perceptions of the importance and relevance of reading tasks (Guthrie \& Klauda, 2016; Schiefele et al., 2012).

With regard to engagement, the reading engagement model of Guthrie and colleagues (Guhrie et al., 2012; Guthrie \& Klauda, 2016) focuses on individuals' commitment of time, effort, and perseverance to reading activities, with these positive aspects of engagement termed "dedication" in the model. Of note is that this focus on time, effort, and persistence in reading mainly captures the behavioral dimension of engagement, in accordance with the notion that engagement involves the visible manifestation of motivation (Eccles \& Wang, 2012). As such, emotional and cognitive dimensions of engagement (Sinatra et al., 2015; Skinner et al., 2014) are not emphasized within this model.

Of note is also that Guthrie and colleagues (Guthrie \& Klauda, 2014, 2016) have argued that motivation and engagement constructs have positive (affirming) as well as negative (undermining) forms. Thus, the positive motivation constructs of perceived competence in reading and valuing of reading are assumed to have perceived difficulty of reading and devaluing of reading as their negative counterparts, and the 
positive behavioral engagement construct of dedication to reading is assumed to have avoidance of reading as a negative counterpart. According to Guthrie and Klauda (2014), the rationale for considering both positive and negative forms of these reading motivation and engagement constructs is that they cannot be conceptualized as simple opposites. For example, a substantial proportion of readers may believe that they are competent readers but still judge the reading task to be difficult, and a substantial proportion of readers may not be dedicated readers but still do not avoid reading.

In accordance with the conceptualization of reading motivation and engagement discussed above, Guthrie and Klauda (2014) developed a 41-item self-report measure to assess the positive reading motivation and engagement constructs of intrinsic reading motivation, perceived competence in reading, valuing of reading, and dedication to reading, as well as the negative reading motivation and engagement constructs of perceived difficulty of reading, devaluing of reading, and avoidance of reading (see also, Guthrie et al., 2013). Support for the seven constructs assumed to underlie participants' scores on this measure was obtained through factor analyses, and construct validity was further indicated by the predictive validity of these constructs (Guthrie et al., 2013) and the effects of an intervention to promote reading motivation and engagement on these constructs (Guthrie \& Klauda, 2014). Moreover, extensive reviews of the literature have provided evidence for unique positive associations between the positive reading motivation and engagement constructs and achievement and unique negative associations between the negative reading motivation and engagement constructs and achievement (Guthrie et al., 2012; Guthrie \& Klauda, 2016; Schiefele et al., 2012).

However, although researchers have made great progress in describing, measuring, and testing reading motivation and engagement constructs in recent years, less is known about students' reading motivation and engagement when reading on the Internet than when reading in conventional-print contexts. This is somewhat paradoxical given that the literacy landscape has changed enormously as the Internet has become a dominant information resource and an invaluable learning tool for students, with students at different educational levels increasingly using the Internet for academic purposes (Bråten et al., 2020; Fraillon et al., 2014; Kammerer et al., 2018). For example, results from the International Computer and Information Literacy Study showed that more than half of the participating eighth and ninth graders from 20 different countries reportedly used the Internet to search for information for study or school work every week (Fraillon et al., 2014). In Norway, in particular, the national curriculum states that all schools must make computers available to all students, and one computer for each student is very common, especially in uppersecondary school (Norwegian Directorate for Education and Training, 2019; vilbli. no, 2019). Still, the role of reading motivation and engagement seems to be underrepresented in accounts of reading that take this development into consideration, such as the new literacies framework of Leu and colleagues (Leu et al., 2013). Symptomatic in this regard is new literacies scholars' lack of attention to reading motivation and 
engagement constructs when discussing individual differences in online research and comprehension (Leu et al., 2016).

This is not to say that researchers interested in learning within Internet technologies have disregarded motivational factors, however. To the contrary, many studies have focused on individuals' perceptions of themselves in relation to the use of information and communication technology (ICT), including the Internet (e.g., Andreassen \& Bråten, 2013; Bråten et al., 2005; Chu, 2010; Janneck et al., 2013; Joo et al., 2000; Sáinz \& Eccles, 2012; Scherer \& Hatlevik, 2017; Shu et al., 2011; Strømsø \& Bråten, 2010; Tsai \& Tsai, 2003, 2010; Turel et al., 2015). In particular, individuals' perceived Internet self-efficacy, that is, their perceived capabilities to use different Internet functions, has been linked to both self-reported and actual behaviors when learning within Internet technologies (e.g., Chu, 2010; Joo et al., 2000; Tsai \& Tsai, 2010). This body of work has not focused on specific reading motivation and engagement constructs, however.

Also, more comprehensive models of motivation and engagement predicting digital reading and ICT literacy have been proposed and tested in the last decade (Naumann, 2015; Senkbeil \& Ihme, 2017; Zylka et al., 2015). Thus, Naumann (2015) modelled relations between engagement in online information seeking and online social interaction, respectively, and students' navigation behavior and digital reading performance. Zylka et al. (2015) provided validation data for a model including five dimensions of ICT engagement: positive ICT self-concept, negative ICT self-concept, social exposure to ICT, interest in computers, and interest in mobile devices. Although both these efforts to investigate the role of motivation and engagement in digital, online literacy contexts referred to the model of reading engagement proposed by Guthrie end colleagues (see above), none of them targeted specific reading and engagement constructs included in that model. Likewise, Senkbeil and Ihme (2017), who tested the structure of an ICT motivation inventory, focused on individuals' motives for using ICT (e.g., information seeking and social exchange) and ICT self-efficacy rather than constructs of reading motivation and engagement.

A notable exception in this regard is Forzani et al.'s (in press) recent development and validation of an instrument for assessing motivations for online reading to learn. However, although these authors built on previous work on offline reading motivation, their measure captured reading motivation quite narrowly by targeting only three dimensions: curiosity/value, self-efficacy, and self-improvement beliefs. Thus, none of the negative reading motivation constructs or behavioral engagement constructs figuring in the reading engagement model of Guthrie and colleagues (Guthrie et al, 2012; Guthrie \& Klauda, 2014, 2016) were targeted by their measure, which also addressed "doing research and reading on the Internet" rather than focusing specifically on reading. Moreover, the measure developed by Forzani et al. (in press) did not differentiate between recreational and academic contexts, and therefore did not target reading on the Internet for academic purposes within a specific domain, as we did in the current study. 
Based on this background analysis, we set out to create a new measure targeting motivation and engagement in Internet reading contexts. This measure was created to capture the specific reading motivation and engagement constructs included in the reading engagement model of Guthrie and colleagues (Guthrie et al., 2012; Guthrie \& Klauda, 2016) and, as such, took those authors' attempt to measure these constructs as its point of departure (Guthrie et al., 2013; Guthrie \& Klauda, 2014). At the same time, however, we ensured that each item on the measure focused on reading motivation and engagement when reading on the Internet for academic purposes.

Many researchers in reading and literacy have highlighted that reading on the Internet and reading in conventional-print contexts differ in important ways (e.g., Cho \& Afflerbach, 2017; Coiro, 2020; Salmerón, Strømsø, Kammerer, Stadtler, $\&$ van den Broek, 2018). For example, reading on the Internet requires different processes with respect to searching for, selecting, evaluating, and integrating textual information than does conventional-print reading. Especially, the increased need to critically evaluate the trustworthiness and accuracy that comes with lower levels of editorial gatekeeping on many websites, has been regarded as a great challenge (Cho \& Afflerbach, 2017; Salmerón et al., 2018). Other challenges have been related to the reading of hypertext, in particular that readers may easily become distracted and confused and lose track of the issue they set out to investigate when trying to assemble a coherent understanding of an issue from a linked network of information (Cho \& Afflerbach, 2017; Delgado et al., 2020; Salmerón et al., 2018). Taken together, such differences suggest that reading motivation and engagement also differ across online and offline reading contexts, with motivation and engagement being particularly important to energize and sustain the reflection and self-monitoring required to critically evaluate information and avoid distraction in Internet reading contexts (Forzani et al., in press). Finally, even reading a downloaded text on a screen without any hyperlinks or other distractions may require additional challenges compared to reading the same text on paper (Delgado et al., 2018). Readers have been found to read faster and overestimate their comprehension when reading digital compared to printed texts (e.g., Ackerman \& Goldsmith, 2011; Lauterman \& Ackerman, 2014; Singer \& Alexander, 2017). One reason for this may be that readers' extensive use of digital media, including the Internet, is paving the way for a habit of mind that constrains readers' processing of digital texts more generally (Wolf, 2018). Reading motivation and engagement may therefore play a more important role in counteracting and overcoming this tendency to process digital texts more superficially.

However, the measure we created targeted not only reading on the Internet but also reading for academic purposes. As noted in Schiefele et al.'s (2012) comprehensive review of the reading motivation literature, reading motivation has been found to be differentially related to reading for school (i.e., academic reading) and reading for enjoyment (i.e., recreational reading). In addition, there are other challenges when reading for academic purposes on the Internet than when reading for academic purposes in general. These particular challenges were reviewed by 


\section{Brandmo Eั I. Bråten}

Bråten et al., (2018), who highlighted the challenges of dealing with unvetted texts, texts not adapted to students' educational levels or prior knowledge, texts presenting conflicting information, and texts written by authors differing with respect to competence and motives. Moreover, dealing with search engine delivery and design of web pages, as well as with reading as a social acivity, can be considered particular challenges of academic reading in an online context (Bråten et al., 2018). Given that reading motivation and engagement may function differently when reading for academic purposes than when reading for other purposes, and that reading for academic purposes on the Internet may be different from reading for academic purposes in general, we considered it pertinent to create a new measure that targeted reading motivation and engagement when reading for academic purposes on the Internet, in particular.

In addition to testing the dimensionality of scores on this measure in a sample of pre-service teachers, we examined whether the proposed reading motivation and engagement constructs could improve the prediction of the time participants spent on the Internet for academic purposes as well as their academic achievement beyond that afforded by differences in gender, educational level, teaching practice, and total time spent on the Internet. The measure that we used was domain-specific in the sense that all items concerned the content domain of education. This domain was considered particularly pertinent to our participants. Moreover, measuring reading motivation and engagement at a domain-general level seems less appropriate because there, presumably, is no such thing as a generally motivated and engaged adult reader of Internet materials. Rather, any adult reader is probably more or less motivated to read on the Internet depending on the domain or topic. This focus on a domainspecific level is consistent with a more general emphasis on contextual factors within academic motivation and learning (National Academies of Sciences, Engineering, and Medicine, 2018; Schunk et al., 2014), with motivational beliefs concerning particular domains likely to increase the predictability of such beliefs for learning and comprehension within those domains (Fives \& Dinsmore, 2018). Of note is that all the items on our measure may easily be adapted to concern other domains or topics than the one we targeted in the present study.

In summary, the present study examined the following three questions:

1. Do the reading and engagement constructs of intrinsic reading motivation, perceived competence in reading, perceived difficulty of reading, valuing of reading, devaluing of reading, dedication to reading, and avoidance of reading underlie participants' scores when reporting on their reading for academic purposes on the Internet?

2. To what extent do these reading motivation and engagement constructs, if identified, contribute to the time spent on the Internet for academic purposes over and above gender, educational level, teaching practice, and total time spent on the Internet?

3. To what extent do these reading and engagement constructs contribute to academic achievement over and above the control variables mentioned in question two? 


\section{Method}

Participants

Participants were 386 pre-service teachers ( $64 \%$ female) from four teacher education programs in a large city in southeast Norway. ${ }^{1}$ In Norway, there are two main tracks of teacher education that include four different programs: a one-year program at postgraduate level that qualifies for teaching in secondary school (grades 8-13) and three five-year master programs that qualify for teaching in primary school (grades 1-7), upper primary and lower secondary school (grades 5-10), and secondary school (grades 8-13), respectively. One-hundred and seventy-three participants attended the one-year postgraduate program, 91 attended the five-year master program qualifying for grades 8-13, and 122 attended the five-year master program qualifying for grades 1-7. The first two programs were located at the University of Oslo and the third was located at Oslo Metropolitan University. Participants ranged in age from 21 to 63 years with an overall mean age of $28.14(S D=5.38)$. The majority of the participants $(83 \%)$ were born in Norway and learned Norwegian as their first language, and the rest were bilingual, most of them raised in Norway, but with parents from different parts of the world. With regard to educational background, $27 \%$ had earned 60 ECTS (European Credit Transfer and Accumulation System) credits, $40 \%$ had earned 180 credits (equivalent to a bachelor's degree), $31 \%$ had earned 300 credits (equivalent to a master's degree), and $2 \%$ had completed a $\mathrm{Ph} . \mathrm{D}$. None of the participants had studied less than one and a half year at postsecondary level. All participants were studying educational topics at the time of data collection. With regard to teaching experience, $45 \%$ of the participants did not have any teaching experience beyond the teaching practice included in the program. The rest varied in teaching experience from part-time practice as a substitute teacher to more than 6 years of full-time teaching practice. However, the vast majority had little teaching experience. Although there were minor variations among the programs, approximately $70 \%$ of the syllabus of our participants consisted of paper-based sources, such as books and compendiums, while approximately $30 \%$ consisted of digital sources located on the Internet, such as journal articles and public documents (e.g., national curricula or documents from the Norwegian Directorate for Education and Training).

One-hundred and seventy-three participants had not completed any exams in educational topics at the time the data were collected. Therefore, only 213 students (69\% female) were included in the analysis addressing our third research question. This subsample consisted of the 91 participants who attended the five-year master program qualifying for grades 8-13 and the 122 participants who attended the five-year master program qualifying for grades $1-7$. These participants ranged in age from 21 to 52 years with an overall mean age of $24.67(S D=3.21)$. With regard to educational background, $49 \%$ of the participants in this subsample had earned 60 ECTS credits, $48 \%$ had earned 180 credits, and 3\% had earned 300 credits. In this subsample, $50.2 \%$ did not have any teaching experience beyond the teaching practice included in the program. 


\section{Brandmo \& I. Bråten}

\section{Materials}

\section{Demographic survey}

A brief survey requested demographic information about age, gender, native language, teacher education program, educational background, and teaching experience. Based on the information provided about educational background, we categorized participants into three educational levels. Thus, the variable termed "educational level" was coded 1 for participants who had earned 60 ECTS credits, 2 for those who had earned 180 credits (equivalent to a bachelor's degree), and 3 for those who had earned 300 credits (equivalent to a master's degree) or more. Due to little variation in teaching experience among the participants, we created the dichotomous variable "teaching practice" by coding no teaching practice beyond that included in the teacher education program as 0 and teaching practice beyond that included in the teacher education program as 1 .

\section{The Internet-Specific Reading Motivation and Engagement Scale}

To assess participants' Internet-specific reading motivation and engagement, we created a measure inspired by Guthrie and Klauda's (2014) 41-item Reading Motivation and Engagement Scale. According to Guthrie and Klauda (2014), reading motivation and engagement can be measured on seven different dimensions, which they labeled intrinsic motivation, perceived competence, perceived difficulty, value, devalue, dedication, and avoidance. As noted above, their focus on both positive (i.e., perceived competence, value, and dedication) and negative (i.e., perceived difficulty, devalue, and avoidance) versions of motivation and engagement constructs is based on the rationale that positive and negative forms cannot be considered simple opposites. In developing items for the Internet-Specific Reading Motivation and Engagement Scale (IRMES), we adapted 27 items from Guthrie and Klauda's (2014) measure to the context of reading on the Internet. For example, the original item, "I could understand all the readings," used to measure perceived competence, was adapted into, "I understand everything I read about educational topics on the Internet." The other 14 items were created by the authors to represent the dimensions defined by Guthrie and Klauda (2014).

Thus, the six items targeting intrinsic reading motivation focused on enjoyment and interest in reading about educational topics on the Internet. The six items targeting the positive reading motivation construct of perceived competence focused on belief in one's capacity to learn from and comprehend what one reads about educational topics on the Internet, whereas the six items targeting the negative reading motivation construct of perceived difficulty focused on the belief that what one reads about educational topics on the Internet is difficult to comprehend. The six items targeting the positive reading motivation construct of value focused on the belief that reading about educational topics on the Internet is useful, relevant, and important, whereas the six items targeting the negative reading motivation construct of devalue focused on the belief that what one reads about educational topics on the Internet is not useful, relevant, or important for one's current or future success. Finally, the 
six items targeting the positive behavioral engagement construct of dedication concerned an intention or willingness to put persistence, time, and effort into reading about educational topics on the Internet, whereas the five items targeting the negative behavioral engagement construct of avoidance concerned an aversion toward reading about educational topics on the Internet.

In addition to targeting motivation and engagement when reading on the Internet, all items on the IRMES were specified such that they concerned the content domain of education. Accordingly, the written instruction emphasized that all statements included in the measure concerned reading information about educational topics on the Internet. However, by adapting this instruction and replacing "educational topics" in each item, the measure can be used to examine motivation and engagement when reading about other domains or topics on the Internet. Participants rated each of the items on a 10-point anchored scale ranging from strongly disagree (1) to strongly agree (10). All items are displayed in Appendix A, which also shows which items were adapted from Guthrie and Klauda (2014) and which were created by the authors.

\section{Time spent on the Internet for various purposes}

As an indication of participants' use of the Internet in general as well as for academic purposes, we asked them about the time they spent on the Internet. First, we asked how many hours they, on average, spent on the Internet per week, regardless of purpose. This variable is labeled "Time spent on the Internet" in further analyses. Second, we asked how many hours they, on average, spent on the Internet per week for academic purposes related to the domain of education. This variable is labeled "Time for academic purposes" in further analyses. Of note is that people have been found to both over- and underestimate the time they spend on the Internet, with frequent Internet users tending to underestimate their time use and less frequent Internet users tending to overestimate it (Araujo et al., 2017; Scharkow, 2016). However, when the time period or content domain is specified, self-reported time use has been found to be more accurate when compared with log data (Scharkow, 2016).

\section{Achievement}

We assessed participants' achievement in the domain of education by having them self-report the average grade obtained on completed examinations in educational topics as part of their teacher education program. Grades were converted from letters to numbers, with F coded as 1 (fail) and A coded as 6 (excellent). One-hundred and seventy-three participants who had not completed any examinations in educational topics at the time of data collection were excluded from statistical analyses including the achievement variable. Of note is that self-reported grades have been found to be highly correlated (approx. .90) with grades provided by instructors, even though students tend to overestimate their grades slightly when self-reporting them (Dickhäuser \& Plenter, 2005; Frucot \& Cook, 1994; Hofer et al., 2012). Further, students' overestimations have been found to be unrelated to gender as well as to self-concept and achievement in the content domain (Dickhäuser \& Plenter, 2005). 


\section{Brandmo Eั I. Bråten}

\section{Procedure}

Data collection took place during regular lectures, with the measures group administered by the first author and a trained research assistant. Participants were informed that participation in the study was voluntary and that the data would be treated anonymously and confidentially. They completed the demographic survey followed by the Internet-Specific Reading Motivation and Engagement Scale before they, finally, responded to the questions regarding the time they spent on the Internet for general and academic purposes, respectively, and reported on their average grades in education. The measures were completed in approximately 15 minutes.

\section{Analytic Approach}

To investigate the construct validity of the Internet-Specific Reading Motivation and Engagement Scale (IRMES), we performed confirmatory factor analysis (CFA) to test how well the theoretical model (i.e., the seven dimensions of reading motivation and engagement) fit the data. In evaluating the model, we examined the sizes of the factor loadings, potential cross-loadings of items, and inter-correlations among factors. To evaluate the overall fit of the model, we used chi-square statistics and the following fit-indices reported by the Mplus software (Muthén \& Muthén, 2012): the comparative fit index (CFI), the root mean square error of approximation (RMSEA), and the standardized root mean square residual (SRMR). After reviewing the literature on cut-off criteria for goodness of fit (Hu \& Bentler, 1998, 1999; Marsh et al., 2004), and taking the current analytic situation (e.g., model complexity) into consideration, we adopted the following criteria for model evaluation: CFI $\geq .90$, RMSEA $\leq .08$, and SRMR $\leq .09$ indicate an acceptable model fit, while CFI $\geq .95$, RMSEA $\leq .05$, and $S R M R \leq .06$ indicate a good model fit. In addition to evaluating the overall model fit, we also computed factor determinacy scores (FDS) and Cronbach's $\alpha$. FDS is a validity coefficient representing a correlation between the estimated factor score and the true factor score that ranges from zero to one and describes how well the factor in question is measured. A factor determinacy score should be at least .80 and preferably above .90, while Cronbach's $\alpha$ should be at least .70 (Brown, 2015).

Further, we performed hierarchical regression analyses to test whether the resulting IRMES factors predicted the time participants reportedly spent on the Internet for academic purposes related to education and their achievement in education, respectively. In these analyses, we included manifest (demographic background variables, time spent on the Internet, and achievement) as well as latent variables (IRMES factors).

\section{Results}

Confirmatory Factor Analyses

Initially we explored all 41 IRMES items with regard to distributional properties (see Appendix A for descriptive statistics). A few items were slightly skewed and peaked, with five items having a skewness value above 1 (1.01-1.16), three items having a 
kurtosis value above 1 (1.05-1.67), and one item having a kurtosis value of -1.12 (see Appendix A). We therefore decided to use robust maximum likelihood estimation.

The first CFA-model was specified in keeping with the hypothesized model, including all 41 items distributed on seven factors (see Appendix A). This model did not fit the data well, $\chi^{2}[758]=2202, p<.001$; CFI $=.79$; RMSEA $=.070,90 \% \mathrm{CI}$ $(.067-.074) ;$ SRMR $=.086$. Seven items had loadings below .50 , and the modification indices indicated that several items had high loadings on more than one factor. We therefore tested several modified models, excluding items with low loadings and items that violated conceptual clarity. ${ }^{2}$ The final model contained 21 items distributed on the seven factors defined by Guthrie and Klauda (2014). This model fit the data quite well, $\chi^{2}[168]=364, p<.001 ; \mathrm{CFI}=.94 ; \mathrm{RMSEA}=.055,90 \% \mathrm{CI}$ $(.047-.063)$; SRMR $=.048$, and FDS and $\alpha$ indicated adequate validity and reliability for each factor (see Table 1). Of note is, however, that several factors were highly correlated (see Table 2). Especially, the factor "Devalue" was extremely highly correlated with the factor "Avoidance" $(r=.99)$. Therefore, we also tested an alternative model with these two factors merged into one. However, the fit for this model was slightly worse than for the one described above. This fact, in combination with

Table 1. Factor Loadings, Validity and Reliability Information for the Internet-Specific Reading Motivation and Engagement Scale

\begin{tabular}{lcccc}
\hline Factor & Item\# & Loading & FDS & $\alpha$ \\
\hline Intrinsic motivation & 13 & .85 & .95 & .85 \\
& 5 & .75 & & \\
Perceived competence & 37 & .83 & .92 & .76 \\
& 27 & .76 & & \\
Perceived difficulty & 23 & .79 & .79 \\
& 1 & .60 & .90 & \\
Value & 9 & .78 & & .86 \\
& 14 & .77 & .95 & \\
Devalue & 11 & .69 & & .79 \\
& 21 & .79 & .96 & \\
Dedication & 16 & .78 & & .76 \\
& 22 & .90 & .92 & \\
Avoidance & 32 & .70 & & \\
& 36 & .81 & .82 \\
& 31 & .79 & & \\
\hline
\end{tabular}

Note. Loadings are standardized; FDS = factor determinacy score; $\alpha=$ Cronbach's alpha. 


\section{Brandmo Ev I. Bråten}

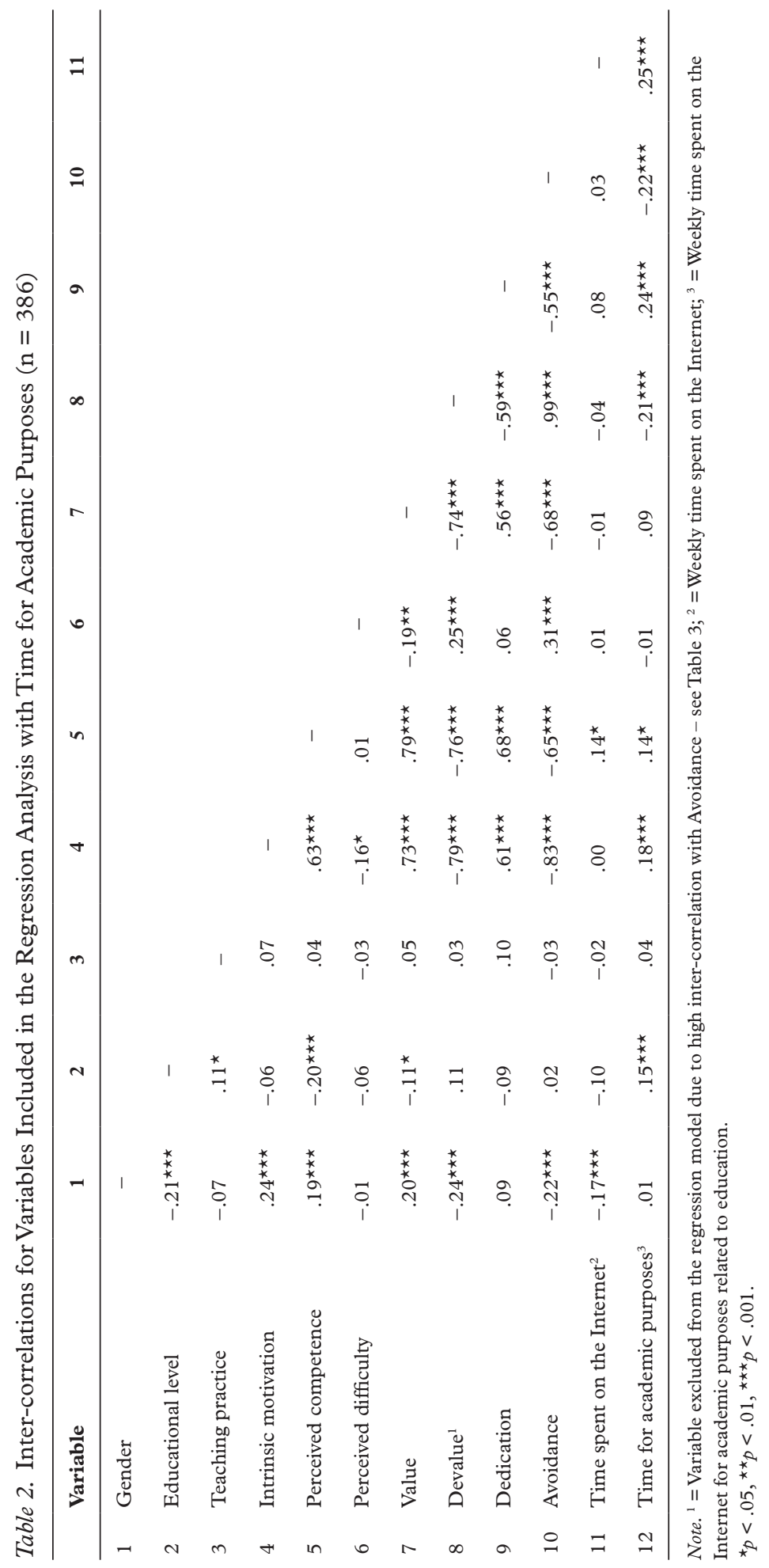


conceptual considerations, led us to retain "Devalue" and "Avoidance" as separate constructs. Still, due to challenges regarding multicollinearity, we excluded the construct of "Devalue" from the regression analyses reported below. ${ }^{3}$

\section{Regression Analyses}

To explore the predictability of the IRMES constructs, we performed two hierarchical regression analyses by means of Mplus, using gender, educational level, teaching practice, and time spent on the Internet for all purposes as control variables. In the first regression analysis, including 386 participants, time used on the Internet for academic purposes was the dependent variable. Inter-correlations between the variables included in this regression analysis are shown in Table 2. As can be seen, the positive reading motivation and engagement constructs of intrinsic reading motivation, perceived competence, and dedication were positively and statistically significantly correlated with time spent on the Internet for academic purposes, while the negative reading motivation and engagement constructs of devalue and avoidance were negatively and statistically significantly correlated with time spent on the Internet for academic purposes.

As can be seen in Table 3, the reading motivation and engagement constructs explained $7.8 \%$ additional variance when entered in Step 3 of the regression analysis (cf., $\Delta R^{2}$ for Step 3 in Table 3). However, only the two behavioral engagement constructs measured by the IRMES were statistically significant unique predictors of

Table 3. Hierarchical Regression Analysis with Time for Academic Purposes

\begin{tabular}{|c|c|c|c|c|c|}
\hline & Variable & $B$ & $S E$ & $\beta$ & $R^{2}$ \\
\hline \multirow[t]{3}{*}{ Step 1} & Gender & 0.43 & 0.50 & .04 & \\
\hline & Educational level & 0.86 & 0.27 & $.15^{\star \star}$ & \\
\hline & Teaching practice & 0.24 & 0.45 & .03 & $2.4 \%$ \\
\hline \multirow[t]{4}{*}{ Step 2} & Gender & 0.93 & 0.45 & $.10^{\star}$ & \\
\hline & Educational level & 1.13 & 0.27 & $.20^{\star \star}$ & \\
\hline & Teaching practice & 0.24 & 0.44 & .03 & \\
\hline & Time spent on the Internet & 0.08 & 0.02 & $.30^{\star \star}$ & $10.9 \%$ \\
\hline \multirow[t]{10}{*}{ Step 3} & Gender & 0.62 & 0.48 & .07 & \\
\hline & Educational level & 1.15 & 0.26 & $.20^{\star \star}$ & \\
\hline & Teaching practice & 0.05 & 0.42 & .01 & \\
\hline & Time spent on the Internet & 0.08 & 0.02 & $.29^{\star \star}$ & \\
\hline & Intrinsic motivation & -0.21 & 0.34 & -.10 & \\
\hline & Perceived competence & -0.44 & 0.39 & -.18 & \\
\hline & Perceived difficulty & 0.18 & 0.22 & .06 & \\
\hline & Value & -0.06 & 0.40 & -.02 & \\
\hline & Dedication & 0.81 & 0.35 & $.24^{\star}$ & \\
\hline & Avoidance & -0.67 & 0.29 & $-.31^{\star}$ & $18.7 \%$ \\
\hline
\end{tabular}

${ }^{\star} p<.05,{ }^{\star \star} p<.001$. 


\section{Brandmo Eั I. Bråten}

time spent on the Internet for academic purposes, with $\beta=.24, p=.05$, for Dedication, and $\beta=-.31, p=.05$, for Avoidance. The overall fit of this model was good, with $\chi^{2}[204]=350, p<.001 ; \mathrm{CFI}=.95$; RMSEA $=.045,90 \%$ CI (.037-.053); SRMR $=.056$.

In the second regression analysis, including 213 participants, we used the same control variables but entered achievement in education as the dependent variable. Inter-correlations between the variables included in this regression analysis are shown in Table 4 . As can be seen, the positive reading motivation and engagement constructs of intrinsic reading motivation and value were positively and statistically significantly correlated with academic achievement, while the negative reading motivation and engagement constructs of perceived difficulty, devalue, and avoidance were negatively and statistically significantly correlated with academic achievement. As can be seen in Table 5, the IRMES constructs explained 5.3\% additional variance in achievement when entered in Step 3 of the regression analysis (cf., $\Delta R^{2}$ for Step 3 in Table 5). However, none of the IRMES constructs were statistically significant unique predictors, presumably due to inter-correlations among the motivation and engagement variables. The overall fit of this model was acceptable, with $\chi^{2}[204]=318$, $p<.001 ; \mathrm{CFI}=.94 ; \mathrm{RMSEA}=.053,90 \% \mathrm{CI}(.042-.064) ; \mathrm{SRMR}=.071$.

Because of the inter-correlations observed among the motivation and engagement variables, we also estimated multicollinearity by computing the variance inflation factor (VIF) and tolerance for these variables in each regression analysis (Cohen et al., 2003). In the first regression analysis, displayed in Table 3, the VIF values ranged from 1.35 to 4.54 and tolerance ranged from 0.22 to 0.74 for the motivation and engagement variables. In the second regression analysis, displayed in Table 5, these values ranged from 1.38 to 4.54 and 0.22 to 0.72 , respectively. Thus, in both analyses, these values could be considered acceptable in terms of collinearity assumptions proposed by statisticians (e.g., Cohen et al., 2003; O’Brian, 2007; Sheather, 2009).

\section{Discussion}

Reading on the Internet may represent other challenges than reading in conventionalprint contexts, for example, because the former may involve high levels of interactivity and non-linearity, as well as a number of other elements (e.g., distractions) not available in printed texts (Cho \& Afflerbach, 2017). Accordingly, reading on the Internet also may involve other processes of reading motivation and engagement than reading in conventional-print contexts. However, so far, little attention has been devoted to specific reading motivation and engagement constructs when reading on the Internet, which may be particularly important to understand the role of such constructs in students' reading on the Internet for academic purposes. Thus, this study represents an effort to create a much needed measure to assess students' motivation and engagement when reading for academic purposes in the context of the Internet. 
Measuring Internet-Specific Reading Motivation

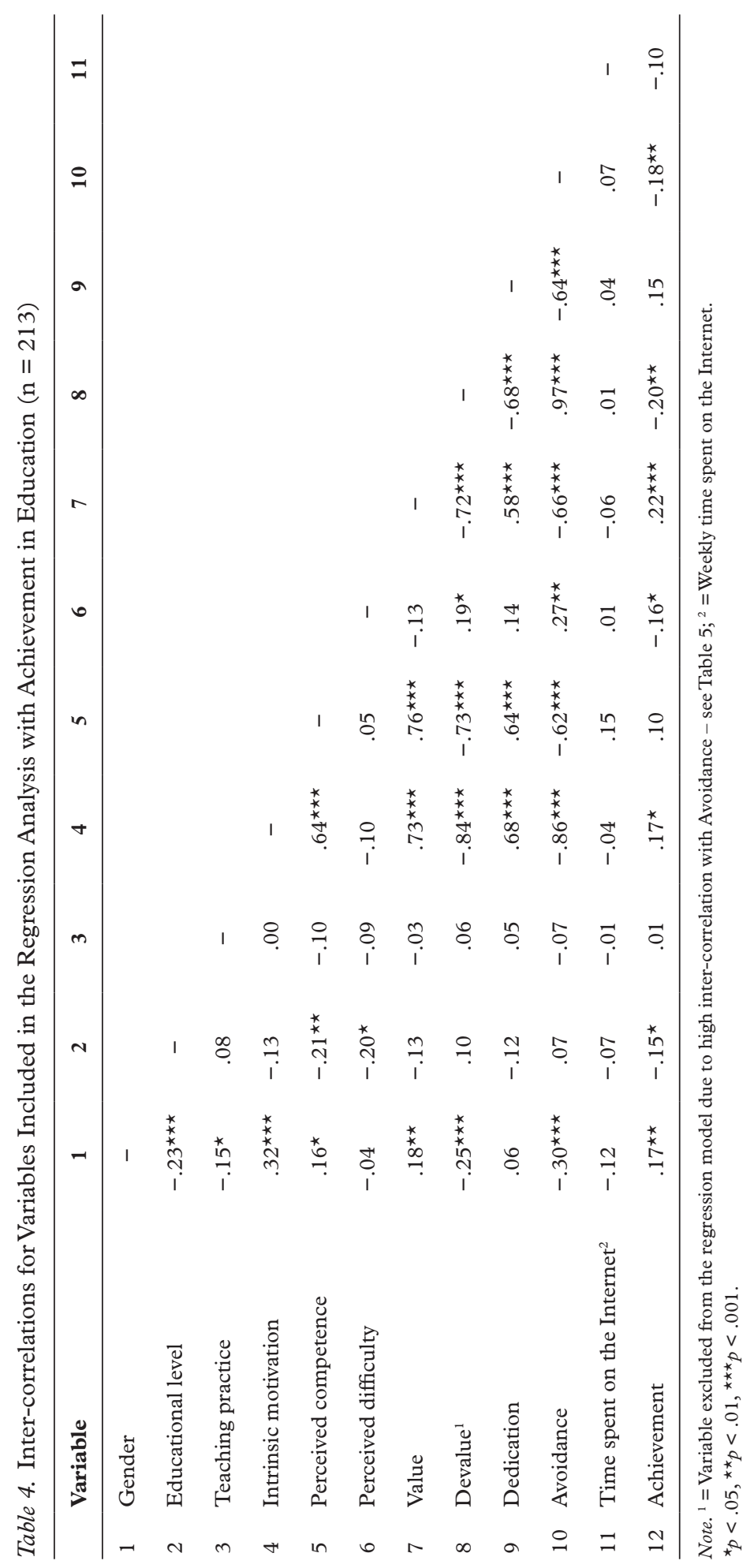




\section{Brandmo Ev I. Bråten}

Table 5. Hierarchical Regression Analysis with Achievement in Education

\begin{tabular}{|c|c|c|c|c|c|}
\hline & Variable & $\boldsymbol{B}$ & $S E$ & $\beta$ & $\boldsymbol{R}^{2}$ \\
\hline \multirow[t]{3}{*}{ Step 1} & Gender & 0.33 & 0.15 & $.17^{\star}$ & \\
\hline & Educational level & -0.19 & 0.13 & -.11 & \\
\hline & Teaching practice & 0.06 & 0.14 & .03 & $4.2 \%$ \\
\hline \multirow[t]{4}{*}{ Step 2} & Gender & 0.28 & 0.16 & .13 & \\
\hline & Educational level & -0.20 & 0.13 & -.11 & \\
\hline & Teaching practice & 0.08 & 0.14 & .04 & \\
\hline & Time spent on the Internet & -0.01 & 0.01 & -.11 & $5.1 \%$ \\
\hline \multirow[t]{10}{*}{ Step 3} & Gender & 0.23 & 0.18 & .11 & \\
\hline & Educational level & -0.21 & 0.14 & -.12 & \\
\hline & Teaching practice & 0.04 & 0.14 & .02 & \\
\hline & Time spent on the Internet & -0.01 & 0.01 & -.10 & \\
\hline & Intrinsic motivation & -0.06 & 0.11 & -.12 & \\
\hline & Perceived competence & -0.09 & 0.12 & -.16 & \\
\hline & Perceived difficulty & -0.10 & 0.08 & -.14 & \\
\hline & Value & 0.15 & 0.11 & .25 & \\
\hline & Dedication & 0.09 & 0.11 & .14 & \\
\hline & Avoidance & -0.03 & 0.09 & -.06 & $10.4 \%$ \\
\hline
\end{tabular}

${ }^{*} p<.05$.

In building on the model of reading engagement proposed by Guthrie and colleagues (Guthrie et al., 2012; Guthrie \& Klauda, 2016; Guthrie \& Wigfield, 2000), we designed our measure to assess the positive reading motivation and engagement constructs of intrinsic reading motivation, perceived competence in reading, valuing of reading, and dedication to reading, as well as the negative reading motivation and engagement constructs of perceived difficulty of reading, devaluing of reading, and avoidance of reading. When examining the scores of the participants by means of confirmatory factor analysis, we found that this measure captured these seven reading motivation and engagement constructs quite well. As such, our study demonstrated that reading motivation and engagement as conceptualized by Guthrie and colleagues also can be brought to bear on students' reading for academic purposes on the Internet.

We further validated the measure we created by comparing the scores on the seven reading motivation and engagement constructs with participants' self-reports of the time spent on the Internet for academic purposes and academic achievement. In general, the zero-order correlations showed that the positive constructs were positively and the negative constructs negatively correlated with both the time spent on the Internet for academic purposes and academic achievement. Moreover, the reading motivation and engagement constructs were found to contribute to both these outcomes over and above gender, educational level, teaching practice, and total time spent on the Internet. Taken together, the results of this study thus provide preliminary 
evidence for the construct validity of the Internet-Specific Reading Motivation and Engagement Scale and lay the foundation for further research with this measure.

It should be noted that formulating all items in reference to reading motivation and engagement in the specific context of Internet-based reading within a particular academic domain, may eliminate potential sources of variation stemming from participants having different reading contexts, domains, or reading purposes in mind while responding to the measure. At the same time, however, we tried to avoid underrepresenting reading motivation and engagement by including all dimensions figuring in the comprehensive reading engagement model of Guthrie and colleagues (2012; Guthrie \& Klauda, 2014, 2016). Thus, in accordance with important principles within construct validity (Kerlinger \& Lee, 2000), this measure was designed to minimize irrelevant variation and represent reading motivation and engagement adequately.

The present study was limited to a sample of Norwegian pre-service teachers and reading about educational topics on the Internet. Therefore, future research with this measure should include other populations and content domains and, preferably, be conducted across cultural contexts. Moreover, future research should compare students' scores on the seven reading motivation and engagement constructs with what they actually do when reading on the Internet to learn about particular topics. In regard to this, follow-up research is currently being conducted with teacher education students who report on their Internet-specific reading motivation and engagement in the domain of education and then use a web-based computer application to select, process, and use texts to perform a reading/writing task on a particular educational topic. In brief, comparing scores on this measure with actual behaviors captured by means of online methodologies such as reading times, navigation behavior, eye movements, and think-alouds is a desirable next step in construct validation.

Because students' reading motivation and engagement may vary considerably across different domains and topics (Bandura, 1997; Fives \& Dinsmore, 2018), and because the items on our measure may easily be adapted to concern other domains and topics, the measure also may be used to compare students' motivation and engagement when reading about different domains or topics on the Internet. Moreover, it may be pertinent to compare students' motivation and engagement when reading on the Internet for academic purposes with their motivation and engagement when reading on the Internet for other, non-academic purposes, such as for entertainment (Schiefele et al., 2012). Thus, participants' scores on the constructs captured by the measure may be compared when the items are framed in terms of reading for academic versus non-academic purposes. In brief, then, because we included item stems in our measure that could be completed in reference to different academic domains or different reading purposes, the role of reading motivation and engagement in online processing and comprehension of information across different domains (e.g., science vs. history) and different purposes (e.g., reading for school vs. reading for entertainment) could be investigated by means of this measure. 


\section{Brandmo Ev I. Bråten}

Finally, this measure may be used to research processes underlying differences in reading digital versus printed texts. Recently, a range of studies have indicated that readers tend to display better comprehension performance when reading printed as compared to digital texts (for reviews, see Clinton, 2019; Delgado et al., 2018; Kong et al., 2018). One viable hypothesis for explaining such differences is the shallowing hypothesis, suggesting that people typically process digital texts more shallowly or superficially because their use of digital media, which often involves quick interactions driven by immediate rewards, promotes a habit of mind that is not conducive to performing challenging reading tasks (Annisette \& Lafreniere, 2017; Delgado et al., 2018). Such potential differences in processing digital versus printed texts may be related to differences in people's motivation and engagement when reading, however, and the measure presented in this article may be employed to study the extent to which differences in reading digital versus printed texts may be mediated by differences in reading motivation and engagement in the two contexts. For example, by changing the phrase "on the Internet" in the item stems to "in books and printed texts" in one version of the measure, it would be possible to investigate whether students' reading motivation and engagement differ across digital and printed reading contexts and whether such differences, in turn, might explain differences in processing and comprehending digital and printed texts.

Research on motivation and engagement in relation to reading and research on such processes in relation to learning within Internet technologies have largely travelled on parallel paths, with different constructs used to understand motivation and engagement, as well as their antecedents and consequences, in the two areas of research. Hopefully, by showing the applicability of constructs developed within reading psychology to the context of reading for academic purposes on the Internet, this study will provide an impetus for much further research on the roles of reading motivation and engagement processes in Internet reading contexts.

\section{Auhtor biography}

Christian Brandmo is Professor of Special Needs Education at the Department of Special Needs Education, University of Oslo.

Ivar Bråten is Professor of Educational Psychology at the Department of Education, University of Oslo.

\section{Notes}

1 Originally, the sample consisted of 394 participants. However, eight participants were excluded due to extreme scores $(>3 S D)$ on variables related to reading time on the Internet. The sample of pre-service teachers in the current work also contributed to data reported by Bråten, Brandmo, and Kammerer (2019). However, the data and analysis included in this article is unique to this study.

2 Because we wanted robust factors with high loadings that would be possible to replicate across different samples, we used the criteria that no factor loadings should be lower than .60 and no cross-loadings should 


\section{Measuring Internet-Specific Reading Motivation}

be higher than .40 . When these criteria were achieved after the testing of three modified models, only one factor (dedication) consisted of more than three (i.e., four ) items. To create a measure in which all factors had the same number of items (i.e., three), we excluded one item that loaded .625 on this factor before we tested our final model including 21 items.

3 Of note is that we also tested several models that were alternatives to the seven-factor model described by Guthrie and Klauda (2014). Thus, we tested a two-factor model with all 24 positive motivation and engagement items distributed on one factor and all 17 negative motivation and engagement items distributed on another factor. This model did not fit the data well, however, with $\chi^{2}[778]=2783, p<.001$; CFI $=.70$; RMSEA $=.082,90 \%$ CI (.078-.085); SRMR $=.085$. The same was true for a two-factor model based on the 21 items we finally retained in which all 12 positive items were distributed on one factor and all 9 negative items were distributed on another factor, with $\chi^{2}[188]=1004, p<.001$; CFI $=.76$; RMSEA = $.106,90 \%$ CI (.100-.113); SRMR = .091. Moreover, we tested several "mirror factor" models in which the items from positive and negative constructs that might seem to be mirrors of each other were distributed on one and the same factor. None of these models fit the data well, however. For example, when we tested a model including all 41 items distributed on four factors of which two combined items from constructs that based on the correlational pattern seemed to be mirrors of each others (i.e., intrinsic motivation and avoidance; value/devalue and perceived competence), $\chi^{2}[773]=2571, p<.001$; CFI $=.73$; RMSEA = $.078,90 \%$ CI (.074-.081); SRMR = .093. The same four-factor model based on the 21 items that we finally retained yielded the following fit estimates: $\chi^{2}[183]=698, p<.001$; CFI $=.85$; RMSEA $=.085,90 \% \mathrm{CI}$ $(.079-.092) ; \mathrm{SRMR}=.066$. Finally, when we tested a mirror factor model with these 21 items distributed on four factors of which three combined items from constructs described as positive and negative, respectively, in Guthrie's model (i.e., value and devalue; perceived competence and perceived difficulty; dedication and avoidance), the following, unacceptable fit estimates were obtained: $\chi^{2}[183]=1024, p<.001$; CFI $=.76$; RMSEA $=.109,90 \%$ CI $(.103-.116) ;$ SRMR $=.095$.

\section{References}

Ackerman, R., \& Goldsmith, M. (2011). Metacognitive regulation of text learning: On screen versus on paper. Fournal of Experimental Psychology: Applied, 17, 18-32. https://doi.org/10.1037/a0022086

Andreassen, R., \& Bråten, I. (2013). Teachers' source evaluation self-efficacy predicts their use of relevant source features when evaluating the trustworthiness of Web sources on special education. British fournal of Educational Technology, 44, 821-836. https://doi.org/10.1111/j.1467-8535.2012.01366.x

Annisette, L. E., \& Lafreniere, K. D. (2017). Social media, texting, and personality: A test of the shallowing hypothesis. Personality and Individual Differences, 115, 154-158. https://doi.org/10.1016/j.paid.2016. 02.043

Araujo, T., Wonneberger, A., Neijens, P., \& de Vreese, C. (2017). How much time do you spend online? Understanding and improving the accuracy of self-reported measures of Internet use. Communication Methods and Measures, 11, 173-190. https://doi.org/10.1080/19312458.2017.1317337

Bandura, A. (1997). Self-efficacy: The exercise of control. W. H. Freeman.

Bråten, I., Braasch, J. L. G., \& Salmerón, L. (2020). Reading multiple and non-traditional texts: New opportunities and new challenges. In E. B. Moje, P. Afflerbach, P. Enciso, \& N. K. Lesaux (Eds.), Handbook of Reading Research (Vol. V, pp. 79-98). Routledge. https://doi.org/10.4324/9781315676302

Bråten, I., Brandmo, C., \& Kammerer, Y. (2019). A validation study of the Internet- Specific Epistemic Justification Inventory with Norwegian pre-service teachers. Fournal of Educational Computing Research, 57, 877-900. https://doi.org/10.1177/0735633118769438

Bråten, I., Stadtler, M., \& Salmerón, L. (2018). The role of sourcing in discourse comprehension. In M. F. Schober, M. A. Britt, \& D. N. Rapp (Eds.), Handbook of discourse processes (2nd. ed., pp. 141-166). Routledge. https://doi.org/10.4324/9781315687384-10

Bråten, I., Strømsø, H. I., \& Samuelstuen, M. S. (2005). The relationship between Internet-specific epistemological beliefs and learning within Internet technologies. Fournal of Educational Computing Research, 33, 141-171. https://doi.org/10.2190/E763-X0LN-6NMF-CB86

Brown, T. A. (2015). Confirmatory factor analysis for applied research (2nd ed.). Guilford.

Cho, B.Y., \& Afflerbach, P. (2017). An evolving perspective of constructively responsive reading comprehension strategies in multilayered digital text environments. In S. E. Israel (Ed.), Handbook of research on reading comprehension (2nd ed., pp. 109-134). Guilford. 


\section{Brandmo E I. Bråten}

Chu, R. J. (2010). How family support and Internet self-efficacy influence the effects of e- learning among higher aged adults: Analyses of gender and age differences. Computers $\mathcal{E}$ Education, 55, 255-264. https:// doi.org/10.1016/j.compedu.2010.01.011

Clinton, V. (2019). Reading from paper compared to screens: A systematic review and meta-analysis. Fournal of Research in Reading, 42, 288-325. https://doi.org/10.1111/1467-9817.12269

Coiro, J. (in press). Toward a multifaceted heuristic of digital reading to inform assessment, research, practice, and policy. Reading Research Quarterly. https://doi.org/10.1002/rrq.302

Cohen, J., Cohen, P., West, S. G., \& Aiken, L. S. (2003). Applied multiple regression/correlation analysis for the behavioral sciences (3rd ed.). Erlbaum. https://doi.org/10.4324/9780203774441

Deci,E.L., \& Ryan, R. M. (2000).The "what" and "why" of goal pursuits: Human needs and the self-determination of behavior. Psychological Inquiry, 11, 227-268. https://doi.org/10.1207/S15327965PLI1104_01

Delgado, P., Stang Lund, E., Salmerón, L., \& Bråten, I. (2020). To click or not to click: Investigating conflict detection and sourcing in a multiple document hypertext environment. Reading and Writing: An Interdisciplinary fournal, 33, 2049-2072. https://doi.org/10.1007/s11145-020-10030-8

Delgado, P., Vargas, C., Ackerman, R., \& Salmerón, L. (2018). Don’t throw away your printed books: A metaanalysis on the effects of reading media on reading comprehension. Educational Research Review, 25, $23-38$. https://doi.org/10.1016/j.edurev.2018.09.003

Dickhäuser, O., \& Plenter, I. (2005). "Letztes Halbjahr stand ich zwei”: Zur Akkuratheit selbst berichteter Noten [On the accuracy of self-reported school marks]. Zeitschrift für Pädagogische Psychologie, 19, $219-224$. https://doi.org/10.1024/1010-0652.19.4.219

Eccles, J., \& Wang, M. (2012). Part I commentary: So what is student engagement anyway? In S. Christensen, A. Reschly, \& C. Wylie (Eds.), Handbook of research on student engagement (pp. 133-145). Springer. https:// doi.org/10.1007/978-1-4614-2018-7_6

Fives, H., \& Dinsmore, D. L. (Eds.) (2018). The model of domain learning: Understanding the development of expertise. Routledge. https://doi.org/10.4324/9781315458014

Forzani, E., Leu, D. J., Li, E. Y., Rhoads, C., Guthrie, J. T., \& McCoach, B. (in press). Characteristics and validity of an instrument for assessing motivations for online reading to learn. Reading Research Quarterly. https://doi.org/10.1002/rrq.337

Fraillon, J., Ainley, J., Schulz, W., Friedman, T., \& Gebhardt, E. (2014). Preparing for life in a digital age:The IEA International Computer and Information Literacy Study international report. Springer.

Frucot, V. G., \& Cook, G. L. (1994). Further research on the accuracy of students' self-reported grade point averages, SAT scores, and course grades. Perceptual and Motor Skills, 79, 743-746. https://doi.org/10.2466/ pms.1994.79.2.743

Guthrie, J. T., \& Klauda, S. L. (2014). Effects of classroom practices on reading comprehension, engagement, and motivations for adolescents. Reading Research Quarterly, 49, 387-416. https://doi.org/10.1002/rrq.81

Guthrie, J. T., \& Klauda, S. L. (2016). Engagement and motivation processes in reading. In P. Afflerbach (Ed.), Handbook of individual differences in reading: Reader, text, and context (pp. 41-53). Routledge. https://doi. org/10.4324/9780203075562

Guthrie, J. T., \& Klauda, S. L., \& Ho, A. N. (2013). Modeling the relationships among reading instruction, motivation, engagement, and achievement for adolescents. Reading Research Quarterly, 48, 9-26. https:// doi.org/10.1002/rrq.035

Guthrie, J. T., \& Wigfield, A. (2000) Engagement and motivation in reading. In M. L. Kamil, P. B. Mosenthal, P. D. Pearson, \& R. Barr (Eds.), Handbook of reading research (Vol. 3, pp. 403-422). Erlbaum. https://doi. org/10.4324/9781315200613

Guthrie, J. T., Wigfield, A., \& Perencevich, K. C. (Eds.) (2004). Motivating reading comprehension. Erlbaum.

Guthrie, J. T., Wigfield, A., \& You, W. (2012). Instructional contexts for engagement and achievement in reading. In S. L. Christenson, A. L. Reschly, \& C. Wylie (Eds.), Handbook of research on student engagement (pp. 601-634). Springer. https://doi.org/10.1007/978-1-4614-2018-7_29

Hofer, M., Kuhnle, C., Kilian, B., \& Fries, S. (2012). Cognitive ability and personality variables as predictors of school grades and test scores in adolescents. Learning and Instruction, 22, 368-375. https://doi. org/10.1016/j.learninstruc.2012.02.003

Hu, L.T., \& Bentler, P. M. (1998). Fit indices in covariance structure modeling: Sensitivity to underparameterized model misspecification. Psychological Methods, 3, 424-453. https://doi.org/10.1037/1082-989X.3.4.424

Hu, L. T., \& Bentler, P. M. (1999). Cutoff criteria for fit indexes in covariance structure analysis: Conventional criteria versus new alternatives. Structural Equation Modeling, 6, 1-55. https://doi.org/10.1080/ 10705519909540118 


\section{Measuring Internet-Specific Reading Motivation}

Janneck, M., Vincent-Hoeper, S., \& Erhardt, J. (2013). The computer-related self concept: A gender-sensitive study. International fournal of Social and Organizational Dynamics in IT, 3, 1-16. https://doi.org/10.4018/ ijsodit. 2013070101

Joo, Y. J., Bong, M., \& Choi, H. J. (2000). Self-efficacy for self-regulated learning, academic self-efficacy, and Internet self-efficacy in Web-based instruction. Educational Technology Research and Development, 48, 5-17. https://doi.org/10.1007/BF02313398

Kammerer, Y., Brand-Gruwel, S., \& Jarodzka, H. (2018). The future of learning by searching the Web: Mobile, social, and multimodal. Frontline Learning Research, 6, 81-91. https://doi.org/10.14786/flr.v6i2.343

Kerlinger, F. N., \& Lee, H. B. (2000). Foundations of behavioral research (4th ed.). Harcourt College Publishers.

Kong, Y., Seo, Y. S., \& Zhai, L. (2018). Comparison of reading performance on screen and on paper: A metaanalysis. Computers $\mathcal{E}$ Education, 123, 138-149. https://doi.org/10.1016/j.compedu.2018.05.005

Lauterman, T., \& Ackerman, R. (2014). Overcoming screen inferiority in learning and calibration. Computers in Human Behavior, 35, 455-463. https://doi.org/10.1016/j.chb.2014.02.046

Leu, D. J., Kiili, C., \& Forzani, E. (2016). Individual differences in the new literacies of online research and comprehension. In P. Afflerbach (Ed.), Handbook of individual differences in reading: Reader, text, and context (pp. 259-272). Routledge. https://doi.org/10.4324/9780203075562

Leu, D. J., Kinzer, C. K., Coiro, J., Castek, J., \& Henry, L. A. (2013). New literacies: A dual-level theory of the changing nature of literacy, instruction, and assessment. In D. E. Alvermann, N. J. Unrau, \& R. B. Ruddell (Eds.), Theoretical models and processes of reading (6th ed., pp. 1150-1181). International Reading Association. https://doi.org/10.4324/9781315110592

Marsh, H. W., Hau, K. T., \& Wen, Z. (2004). In search of golden rules: Comment on hypothesis testing approaches to setting cutoff values for fit indexes and dangers in overgeneralizing Hu and Bentler's (1999) findings. Structural Equation Modeling, 11, 320-341. https://doi.org/10.1207/s15328007sem1103_2

Muthén, L. K., \& Muthén, B. (2012). Mplus user's guide Version 7. Muthén \& Muthén.

National Academies of Sciences, Engineering, and Medicine (2018). How people learn II: Learners, contexts, and cultures. Washington, DC: The National Academies Press. https://doi.org/10.17226/24783

Naumann, J. (2015). A model of online reading engagement: Linking engagement, navigation, and performance in digital reading. Computers in Human Behavior, 53, 263-277. https://doi.org/10.1016/j.chb.2015.06.051

$\mathrm{Ng}$, C., \& Graham, S. (2018). Improving literacy engagement [Special issue]. Fournal of Research in Reading, 41, 615-739. https://doi.org/10.1111/1467-9817.12252

Norwegian Directorate for Education and Training (2019). Framework for basic skills. https://www.udir.no/inenglish/Framework-for-Basic-Skills/

O’Brian, R. M. (2007). A caution regarding rules of thumbs for variance inflation factors. Quality E Quantity, 41, 673-690. https://doi.org/10.1007/s11135-006-9018-6

Reeve, J. (2012). A self-determination theory perspective on student engagement. In S. Christensen, A. Reschly, \& C. Wylie (Eds.), Handbook of research on student engagement (pp. 149-173). Springer. https://doi. org/10.1007/978-1-4614-2018-7

Sáinz, M., \& Eccles, J. (2012). Self-concept of computer and math ability: Gender implications across time and within ICT studies. Fournal of Vocational Behavior, 80, 486-499. https://doi.org/10.1016/j.jvb.2011.08.005

Salmerón, L., Strømsø, H. I., Kammerer,Y., Stadtler, M., \& van den Broek, P. (2018). Comprehension processes in digital reading. In M. Barzillai, J. Thomson, S. Schroeder, \& P. van den Broek (Eds.), Learning to read in a digital world (pp. 91-120). John Benjamins. https://doi.org/10.1075/swll.17

Scharkow, M. (2016). The accuracy of self-reported Internet use: A validation study using client log data. Communication Methods and Measures, 10, 13-27. https://doi.org/10.1080/19312458.2015.1118446

Sheather, S. (2009). A modern approach to regression with $R$. Springer. https://doi.org/10.1007/978-0-387-09608-7

Scherer, R., \& Hatlevik, O. E. (2017). "Sore eyes and distracted" or "excited and confident"? The role of perceived negative consequences of using ICT for perceived usefulness and self-efficacy. Computers $\mathcal{E}$ Education, 115, 188-200. https://doi.org/10.1016/j.compedu.2017.08.003

Schiefele, U., Schaffner, E., Möller, J., \& Wigfield, A. (2012). Dimensions of reading motivation and their relation to reading behavior and competence. Reading Research Quarterly, 47, 427-772. https://doi.org/ 10.1002/RRQ.030

Schunk, D. H., Meece, J. L., \& Pintrich, P. R. (2014). Motivation in education: Theory, research, and applications (4th ed.). Pearson Merrill Prentice Hall.

Senkbeil, M., \& Ihme, J. M. (2017). Motivational factors predicting ICT literacy: First evidence on the structure of an ICT motivation inventory. Computers $\mathcal{E}$ Education, 108, 145-158. https://doi.org/10.1016/j. compedu.2017.02.003 


\section{Brandmo E I. Bråten}

Shu, Q., Tu, Q., \& Wang, K. (2011). The impact of computer self-efficacy and technology dependence on computer-related technostress: A social cognitive theory perspective. International fournal of HumanComputer Interaction, 27, 923-939. https://doi.org/10.1080/10447318.2011.555313

Sinatra, G. M., Heddy, B. C., \& Lombardi, D. (2015). The challenges of defining and measuring student engagement in science. Educational Psychologist, 50, 1-13. https://doi.org/10.1080/00461520.2014. 1002924

Singer, L. M., \& Alexander, P. A, (2017). Reading across mediums: Effects of reading digital and print texts on comprehension and calibration. Fournal of Experimental Education, 85, 155-172. https://doi.org/10.1080/0 0220973.2016 .1143794

Skinner, E. A., Kindermann, T. A., Connell, J. P., \& Wellborn, J. G. (2009). Engagement and disaffection as organizational constructs in the dynamics of motivational development. In K. R. Wentzel \& A. Wigfield (Eds.), Handbook of motivation at school (pp. 223-245). Routledge.

Skinner, E. A., \& Pitzer, J. R. (2012). Developmental dynamics of student engagement, coping, and everyday resilience. In S. Christensen, A. Reschly, \& C. Wylie (Eds.), Handbook of research on student engagement (pp. 21-45). Springer. https://doi.org/10.1007/978-1-4614-2018-7

Skinner, E. A., Pitzer, J. R., \& Brule, H. (2014). The role of emotion in engagement, coping, and the development of motivational resilience. In R. Pekrun \& L. Linnenbrink-Garcia (Eds.), International Handbook of Emotions in Education (pp. 331-347). Routledge. https://doi.org/10.4324/9780203148211

Strømsø, H. I., \& Bråten, I. (2010). The role of personal epistemology in the self-regulation of Internet-based learning. Metacognition and Learning, 5, 91-111. https://doi.org/10.1007/s11409-009-9043-7

Tsai, M.-J., \& Tsai, C.-C. (2003). Information searching strategies in web-based science learning: The role of Internet self-efficacy. Innovations in Education and Teaching International, 40, 43-50. https://doi. org/10.1080/1355800032000038822

Tsai, M.-J., \& Tsai, C.-C. (2010). Junior high school students' Internet usage and self-efficacy: A re-examination of the gender gap. Computers $\mathcal{E}$ Education, 54, 1182-1192. https://doi.org/10.1016/j.compedu.2009.11.004

Turel, V., Calik, S., \& Doganer, A. (2015). Tertiary students' ICT self-efficacy beliefs and the factors affecting their ICT-use. International fournal of Information and Communication Technology Education, 11, 90-104. https://doi.org/10.4018/ijicte.2015040108

vilbli.no (2019). Free teaching aids and equipment. https://www.vilbli.no/en/en/no/gratis-laeremidler-og-utstyr/ a/027276

Wigfield, A., \& Eccles, J. S. (2000). Expectancy-value theory of achievement motivation. Contemporary Educational Psychology, 25, 68-81. https://doi.org/10.1006/ceps.1999.1015

Wigfield, A., Gladstone, J. R., \& Turci, L. (2016). Beyond cognition: Reading motivation and reading comprehension. Child Development Perspectives, 10, 190-195.

Wolf, M. (2018). Reader, come home: The reading brain in a digital world. Harper.

Zylka, J., Christoph, G., Kroehne, U., Hartig, J., \& Goldhammer, F. (2015). Moving beyond cognitive elements of ICT literacy: First evidence on the structure of ICT engagement. Computers in Human Behavior, 53, 149-160. https://doi.org/10.1016/j.chb.2015.07.008 


\section{Measuring Internet-Specific Reading Motivation}

\section{Appendix A}

Descriptive Statistics for the Motivation and Engagement Items

\begin{tabular}{|c|c|c|c|c|c|}
\hline \# & Wording & Mean & $S D$ & Skew & Kurt \\
\hline & Intrinsic motivation & & & & \\
\hline $13^{\star}$ & I find it interesting to read about educational topics on the Internet. & 5.75 & 2.36 & -0.14 & -0.67 \\
\hline $5^{\star}$ & I think it is fun to read about educational topics on the Internet. & 5.53 & 2.36 & -0.08 & -0.64 \\
\hline 10 & I often read about educational topics on the Internet during my free time. & 3.12 & 2.13 & 1.01 & 0.40 \\
\hline 35 & I read as much as I can about educational topics on the Internet. & 3.58 & 2.32 & 0.81 & -0.19 \\
\hline 8 & $\begin{array}{l}\text { When I read about educational topics on the Internet, I may become } \\
\text { so engaged that I lose track of time. }\end{array}$ & 3.03 & 2.33 & 1.14 & 0.42 \\
\hline \multirow[t]{2}{*}{$37^{\star}$} & I enjoy reading about educational topics on the Internet. & 5.25 & 2.42 & 0.06 & -0.72 \\
\hline & Perceived competence & & & & \\
\hline 41 & I understand everything I read about educational topics on the Internet. & 5.26 & 2.32 & -0.02 & -0.78 \\
\hline $27^{\star}$ & $\begin{array}{l}\text { I find solutions to academic issues by reading about educational topics } \\
\text { on the Internet. }\end{array}$ & 5.51 & 2.32 & -0.15 & -0.65 \\
\hline $23 \star$ & $\begin{array}{l}\text { I obtain key information on educational topics by reading about them } \\
\text { on the Internet. }\end{array}$ & 5.49 & 2.54 & -0.10 & -0.88 \\
\hline 6 & $\begin{array}{l}\text { The main ideas of what I read about educational topics on the Internet are } \\
\text { easy to understand. }\end{array}$ & 5.72 & 2.02 & -0.07 & -0.34 \\
\hline $1^{\star}$ & $\begin{array}{l}\text { I figure out the meaning of central academic concepts by reading } \\
\text { about educational topics on the Internet. }\end{array}$ & 5.84 & 2.54 & -0.06 & -0.94 \\
\hline \multirow[t]{2}{*}{12} & $\begin{array}{l}\text { I understand the connection between the various educational topics I } \\
\text { read about on the Internet. }\end{array}$ & 6.37 & 1.97 & -0.15 & -0.31 \\
\hline & Perceived difficulty & & & & \\
\hline $9^{\star}$ & $\begin{array}{l}\text { What I read on the Internet about educational topics is far too difficult for } \\
\text { me. }\end{array}$ & 3.09 & 1.94 & 1.00 & 0.62 \\
\hline $14^{\star}$ & What I read about educational topics on the Internet only confuses me. & 2.92 & 1.70 & 1.12 & 1.67 \\
\hline 33 & $\begin{array}{l}\text { It is difficult to gain a good academic understanding by reading about } \\
\text { educational topics on the Internet. }\end{array}$ & 4.80 & 2.34 & 0.29 & -0.66 \\
\hline $11^{\star}$ & $\begin{array}{l}\text { I have difficulty explaining what I read on the Internet about educational } \\
\text { topics to other students. }\end{array}$ & 3.14 & 1.86 & 0.94 & 0.63 \\
\hline 17 & $\begin{array}{l}\text { I'm seldom able to find good answers to academic questions by } \\
\text { reading about educational topics on the Internet. }\end{array}$ & 4.10 & 2.02 & 0.63 & 0.01 \\
\hline \multirow[t]{2}{*}{34} & $\begin{array}{l}\text { It is difficult to grasp the main ideas of what I read about educational } \\
\text { topics on the Internet. }\end{array}$ & 3.99 & 2.15 & 0.72 & -0.02 \\
\hline & Value & & & & \\
\hline 3 & I gain useful knowledge by reading about educational topics on the Internet. & 6.27 & 2.28 & -0.32 & -0.46 \\
\hline $21^{\star}$ & $\begin{array}{l}\text { I can relate what I read about educational topics on the Internet to } \\
\text { educational practice. }\end{array}$ & 6.52 & 2.01 & -0.22 & -0.27 \\
\hline 7 & It is very important for me to read about educational topics on the Internet. & 4.19 & 2.37 & 0.46 & -0.48 \\
\hline 38 & $\begin{array}{l}\text { I can use what I read about educational topics on the Internet in many } \\
\text { contexts. }\end{array}$ & 6.09 & 2.24 & -0.21 & -0.43 \\
\hline
\end{tabular}




\begin{tabular}{|c|c|c|c|c|c|}
\hline \# & Wording & Mean & $S D$ & Skew & Kurt \\
\hline $16^{\star}$ & $\begin{array}{l}\text { What I read about educational topics on the Internet will help me in future } \\
\text { studies or work. }\end{array}$ & 6.66 & 2.10 & -0.29 & -0.31 \\
\hline \multirow[t]{2}{*}{$22^{\star}$} & $\begin{array}{l}\text { I learn something valuable by reading about educational topics on the } \\
\text { Internet. }\end{array}$ & 6.45 & 2.13 & -0.26 & -0.36 \\
\hline & Devalue & & & & \\
\hline 40 & $\begin{array}{l}\text { I cannot personally relate to what I read about educational topics on the } \\
\text { Internet. }\end{array}$ & 4.65 & 2.56 & 0.40 & -0.64 \\
\hline $32 \star$ & What I read about educational topics on the Internet is not useful to me. & 3.10 & 1.96 & 0.84 & 0.19 \\
\hline $36^{\star}$ & Reading about educational topics on the Internet is a waste of time. & 3.20 & 2.17 & 0.89 & 0.03 \\
\hline $31^{\star}$ & Reading about educational topics on the Internet is not important to me. & 4.97 & 2.84 & 0.29 & -1.12 \\
\hline 19 & $\begin{array}{l}\text { Other academic activities are more important to me than reading about } \\
\text { educational topics on the Internet. }\end{array}$ & 7.41 & 2.20 & -0.58 & -0.53 \\
\hline 26 & $\begin{array}{l}\text { What I read about educational topics on the Internet will not be of any help } \\
\text { in the future. }\end{array}$ & 2.91 & 2.01 & 1.16 & 1.06 \\
\hline
\end{tabular}

\section{Dedication}

24 Even if what I read about educational topics on the Internet can be difficult, $\quad \begin{array}{llll}5.87 & 2.37 & -0.01 & -0.72\end{array}$ I don't give up. $28 \star$ I spend more time and effort on reading about educational topics on
the Internet than other students.

15 I am very persistent when reading about educational topics on the $\begin{array}{lllll}4.35 & 2.09 & 0.43 & -0.09\end{array}$ Internet.

2 Every time I read about educational topics on the Internet, I work hard. $\quad \begin{array}{lllll}4.50 & 2.12 & 0.49 & -0.09\end{array}$

18* I make sure I set aside enough time to read about educational topics on the $\quad \begin{array}{llll}3.20 & 2.01 & 1.05 & 1.05\end{array}$ Internet.

$30^{\star}$ I put a lot of effort into reading about educational topics on the Internet.

$\begin{array}{llll}3.68 & 2.16 & 0.82 & 0.16\end{array}$

\section{Avoidance}

29 When I read about educational topics on the Internet, I seldom complete

$\begin{array}{llll}4.69 & 2.51 & 0.28 & -0.88\end{array}$ what I start on.

25* I read as little as possible about educational topics on the Internet.

$\begin{array}{llll}4.22 & 2.63 & 0.64 & -0.53\end{array}$

$39 \star$ I avoid reading anything about educational topics on the Internet.

$\begin{array}{llll}3.93 & 2.66 & 0.73 & -0.45\end{array}$

4 I put as little effort as possible into reading about educational topics on the

2.41

$0.52-0.54$ Internet.

$20 \star$ When I read about educational topics on the Internet, I feel that I'm wasting my time.

Note. ${ }^{\star}=$ Items included in the final factor solution; $S D=$ standard deviation; Skew = skewness; Kurt = kurtosis; items in italics are adapted from Guthrie and Klauda (2014). 